Administrative Issues Journal: Connecting Education, Practice, and Research, Summer 2018, Vol. 8, No. 1: 1-17. DOI: 10.5929/2018.8.1.1

\title{
School board governance in changing times: A school's transition to policy governance
}

\author{
Katherine Curry, Ed.D. \\ Sean Kinder, Doctoral Candidate in Educational Leadership and Policy Studies \\ Tania Benoiton, Doctoral Candidate in Educational Leadership and Policy Studies \\ Jessica Noonan, Doctoral Candidate in Educational Leadership and Policy Studies \\ Oklahoma State University
}

\begin{abstract}
The expansion of the school choice movement and greater flexibility allowed by Every Student Succeeds Act (ESSA) means that education governance is emerging as an important issue for school effectiveness. This longitudinal case study sought to gain an understanding of the implementation of a new governance structure, Policy Governance, in a private, independent school with deeply entrenched culture and patterns of behavior. Findings suggest an immediate positive influence on leadership and culture in the district, including a "trickle down" effect on shared leadership. However, challenges to sustainability indicate that even strict adherence to the model, unanimous support among board members, and strong board and administrator leadership may not be enough to support sustainability.
\end{abstract}

Keywords: case study, policy governance, governance, school board, leadership

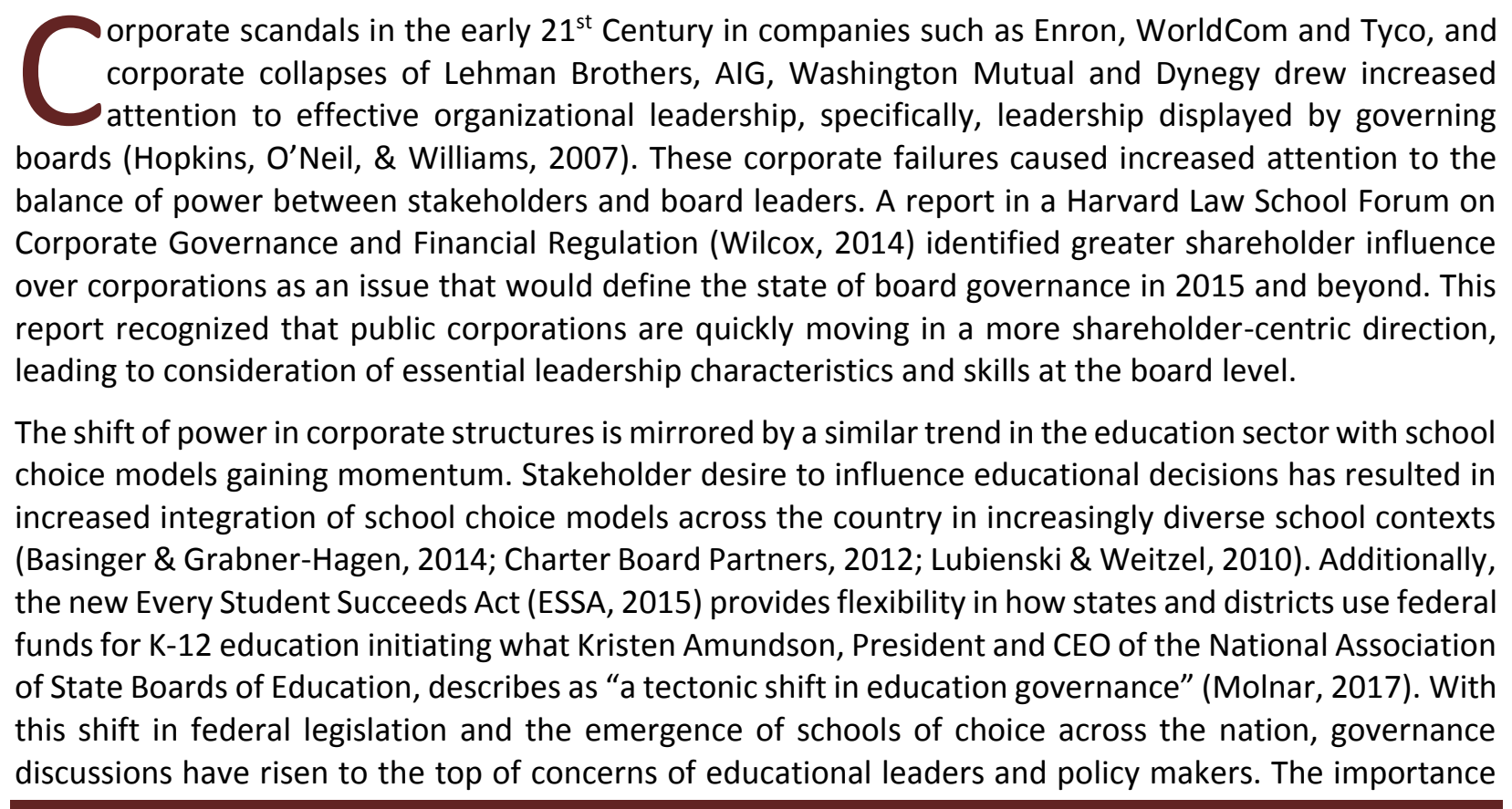


of establishing effective governing boards is further emphasized by The Charter Friends National Network (2000a) by stating, "the success of the charter school -in fact the success of the charter school movement-rests on the success of the charter school board" (p. 6). However, little guidance exists for school board leadership (Basinger \& Grabner-Hagen, 2014) signifying a need for better understandings of effective governance strategies in this rapidly changing educational context (Basinger \& Grabner-Hagen, 2014; Charter Board Partners, 2012).

\section{Problem/Purpose}

Choice schools and the influence of ESSA will result in an innovation in governance. These changes, which will ultimately lead to decentralized governance strategies, give enhanced influence to a variety of stakeholders, including authorizers/sponsors, board members, school leaders and parents. In theory, decentralization comes with the advantage of increased autonomy from state and federal mandates in exchange for enhanced accountability (Gawlik, 2015) resulting in an enhanced sense of ownership and responsibility as stakeholders become involved in the organization. This shared ownership-can benefit students as stakeholders work together to promote educational goals.

Decentralization can also create challenges concerning decision-making and alignment of responsibility (Allen \& Mintrom, 2010; Karanxha, 2013). Tensions often arise in knowing who is in control and who is responsible for decisions within a decentralized organization (Allen \& Mintrom, 2010; Charter Board Partners, 2012; Ford \& Ihrke, 2017). Moe (2000) suggests that one of the ironies of democracy (decentralization) is that educational leaders "have difficulty contributing to the quality of democratic government precisely because they are democratically controlled" (p. 142). The resulting tension among members of the organization, such as school board members and administrators (Charter Board Partners, 2012), can threaten the existence of the organization. The purpose of this study, therefore, was to understand a change in governance in an independent school where role confusion had complicated the operation of the organization. Specifically, this case study sought to understand a change in governance in a private, independent school that had been in existence for approximately 30 years.

\section{Research Questions}

How does the change in governance influence leader (administrator and board) capacity to fulfill district goals in this private, independent school?

\section{Sub-questions:}

1. How do leaders (board and administrator) experience their roles in the new governance structure?

2. What are administrator and board member perceptions of how this change in governance influences the functioning of the organization?

3. What are leaders' perceptions of obstacles to sustained effectiveness of this governance model and what safeguards are needed for sustainability?

\section{History of School Governance}

Local school boards have served as the primary governing entity of public schools for the last 200 years (Hopkins, O'Neil, \& Williams, 2007). One primary purpose of the school board, as identified by the National School Board Association (2015), has been to "advance student achievement through strong local governance" (para. 4). As indicated in this defining purpose, public education in the United States has, historically, had its roots in policy, management and financial control at the local level (Kirst, 2007). Before 
long, however, a strong nationalizing force had consequences concerning the governance of schools. This force, the professionalization of the teaching profession through professional standards for administration, teaching, curriculum and testing, gained its strength in the final decades of the nineteenth century (Kirst, 2007). Additionally, at that time, during the early 1900s, disclosures of widespread municipal corruption in schools led to the belief that centralization of power in a chief executive, or superintendent, who was charged with working with his/her local school board to exercise strong control over education policy, was the answer to educational effectiveness.

Another turning point in school governance began after Moscow launched Sputnik in the 1950s, and educational systems in the U.S. came under intense scrutiny (Kapalka Richerme, 2012; Resnick, 2006). Further, an emphasis on desegregation in the 1960s and 1970s caused decline of confidence in schools (Berliner \& Biddle, 1996; Sampson, 2017) as the public doubted the ability of American schools to provide equal educational opportunities to students (Kirst, 2007). The federal Elementary and Secondary Education Act of 1965 (ESEA) signaled a substantial change in public perception of education in the U.S. because it signaled to the public that schools were not addressing the needs of children with disabilities, minority language students and other students with specific learning needs (Jennings, 2015). Although the Reagan administration of the 1980s attempted to scale back federal involvement in education with an initial attempt to dismantle the Department of Education (McGuinn, 2015), equity concerns caused legislators to retain their focus, and emphasis changed to accountability for student outcomes (Kirst, 2007). State education agencies (SEAs) grew during that time as state boards of education became more involved in school affairs. States began to enjoy unprecedented involvement in areas such as academic standards, curriculum, graduation requirements and accountability, essentially overriding the authority of the local school board in these areas.

The passage of No Child Left Behind in 2001 highlighted the involvement of the federal government in education. This legislation extended the approach of the ESEA and compelled states to provide documentation of student outcomes through mandated assessment, accountability and performance requirements. In 2008, Obama's \$5 billion Race to the Top (RTT) program further entrenched the expansion of accountability, testing and curriculum standards as states competed to qualify for funding. A change happened in 2015, however, with the passage of Every Student Succeeds Act (ESSA), in which the federal government included provisions encouraging local innovation. Currently, evidence suggests that state laws have prevented a surge in local control of education reform (Posamentier, Lake, \& Hill, 2017). However, the rise of the school choice movement and attention given to governance by the National School Boards Association suggests that this prevention is unlikely to prevail.

The National Conference of State Legislatures (NCSL, 2017) documents that the options for choice education in the U.S. are continuing to grow. As of January 2017, 43 states and the District of Columbia had enacted legislation permitting charter schools. These schools operate outside of the traditional school governance structure and exercise enhanced accountability in exchange for high levels of autonomy in decision making (NCSL, 2017), emphasizing control at the local level. In addition, as of January 2017, 27 states had provided support and incentives for parents to choose private schools in place of public schools (NCSL, 2017). Options in the private sector include school vouchers, scholarships in the form of tax credits, and personal tax credits and deductions. The choice model environment appears to be the new norm for parents, educators and policymakers, who are demanding more local control with flexibility that is designed to address and meet the needs of individual students.

\section{Governance of Schools of Choice}


School boards, both public and private, share a common responsibility to secure effectiveness of the organization over which they govern. Sample duties of both public and private school boards include establishing a vision/mission, setting educational policies of the school, maintaining accountability for student achievement, appointing the Chief School Administrator and evaluating the effectiveness of the Board's policy decisions (Hopkins, O'Neil, \& Williams, 2007; Smith, 2003). However, very little empirical research exists regarding the effectiveness of choice school governance models (Poultney, 2013). What is known is that their governance structure typically aligns with a "stewardship" or decentralized model (James et al., 2010; James et al., 2012) where a focus is placed on empowering key leaders to meet organizational goals (Poultney, 2013). Private school boards may also follow a "historical model" (Marx \& Davis, 2012), commonly used among nonprofit boards, where board members serve multi-purposes as they govern the organization while also serving as much needed volunteers to assist with management responsibilities while the organization is forming. Both models, however, present specific challenges to organizational effectiveness as the lines of responsibility and role configuration often become blurred as the organization grows and matures. This tension is among the most common problems identified by traditional public, charter and private schools (Charter Board Partners, 2012; Public Agenda, 2001).

According to Grignano, Director of the Charter Schools Project at Duquesne University, "meddlesome boards who become entangled with issues normally entrusted to administrators or teachers" are among the most common governance problems facing charter schools (Charter Friends National Network, 2000b, p. 10). Evidence suggests that this same problem is evidenced in the private school sector, as well (Allen \& Mintron, 2010). Specifically, poorly defined leadership roles and responsibilities can diminish educational outcomes and severely limit leadership capacity. Additionally, specific interests of governing individuals, poorly defined roles and responsibilities, and the clamor of incongruous voices often leave little room for attention to the kind of innovation that leads to the creation of effective, sustainable learning environments in independent schools (Charter Friends National Network, 2000a; Moe, 2000).

\section{Theoretical Framework: Policy Governance}

One framework that offers insight into the governance of independent schools is Policy Governance because of its emphasis on clear division of roles and responsibilities between board members and employees. John Carver (1990) introduced the concept of Policy Governance (PG) to meet some of the challenges facing nonprofit boards in the financial climate of the 1980s and 1990s including passive "rubber-stamping" boards (Murray, 2010), meddlesome "interfering" boards (Marx \& Davis, 2012; Murray, 2010) and the failure of boards to exercise their rightful authority over the organization (Carver, 2010). Carver (2010) explains, "without recognition or skills in exercising group authority, defaulting on governance is assured" (p. 154).

Carver sought to develop a global theory of governance that recognized governance as a "social construct rather than a natural phenomenon" (Carver, 2010, p. 150). He recognized a deficit in understandings in that most analyses of board effectiveness were done from the perspective of evaluating current board practices rather than evaluation anchored in the perspective of the actual purpose of governing boards (Carver, 2010). Consequently, Carver (2010) argued that a "descriptive theory" is detrimental to the work of governing boards because it results in a limited perspective that "constrains tomorrow's possibilities by today's practices" (p. 151). Instead, he insisted upon a "prescriptive theory" that would "exist to discipline and guide" rather than "explain and predict" effective board work (Carver, 2010, p. 151). His resulting work has gained attention as a market-oriented approach to board governance (Carver, 1990; Williams, 2010) primarily utilized in not-for-profit organizations. 
One principle of the PG framework, autonomous delegation of management responsibility to the Chief Executive Officer, is one of the most well-known theories of governance worldwide (Nobbie \& Brudney, 2003) and much is known about the effectiveness of this approach in nonprofit organizations (Carver, 2001). However, the application of this framework has just recently been studied in educational settings (Useem, 2009). This understanding is important because understanding the influence of PG on leadership capacity, both board and administrator, can offer insight into governance in the rapidly changing landscape of choice education in the United States.

\section{Delineation of Roles and Responsibility in Policy Governance}

The primary premise behind PG is that PG "invests the board with responsibility for long-term policy planning and the Chief Executive Officer (CEO) with responsibility for managing the agency within the policies developed by the board" (Williams, 2010, p. 295). The clarification of roles is fundamental to PG as its emphasis is on a clear distinction between the governance role of the board and the management role of the CEO (Carver, 2010). PG encourages an "activist" role to board governance with greater board control for guiding organizational outcomes (Carver, 2010, p. 154). However, the "how" of meeting organizational outcomes is delegated entirely to the CEO and guided only by "limitations" developed by the board for guiding CEO decisions and activities. PG includes precise methods for delegating managerial authority to the CEO of the organization through the establishment of organizational goals (referred to as "ends"), high standards for CEO accountability, and guidelines that act as a framework for organizational management (referred to as "limitations"). Delegation of authority from the board to the CEO is meant to provide an organizational authority structure that is "rigorous, fair, and empowering." In sum, PG emphasizes CEO leadership within the organization and board leadership over the organization (Carver, 2010, p. 154). Table 1 provides an outline of the theoretical foundations of PG and resulting expectations and responsibilities of involved parties.

\section{Limitations of Policy Governance}

Although PG (Carver, 2001) is widely recognized as a market-oriented model that is consistent with "new and innovative practices" (Williams, 2010, p. 295), it is not without critics. Primary criticism focuses on its call to implement the model with complete fidelity through a "mechanistic adherence to prescribed practices" (Williams, 2010, p. 296). Williams (2010) suggests that, once implemented, the model actually discourages a thorough examination of organizational failures because blame for failure to meet organizational goals under PG is typically attributed to "improper execution" of the model or failure to adhere to a complete "paradigm shift" (Williams, 2010, p. 296). Additional criticism of PG includes observations that the model offers little explanation about "how" to recruit board governors that can successfully sustain the model and that the model offers little explanation of how to adhere to the ideal of "separation of roles and authority" during times of organizational crisis (Oliver, 1999). Scott (1998) argues that PG, because of its strict requirement of adherence to the framework, fails to take into account local context and disregards local practices, meanings, and local history and environments. These criticisms raise important opportunities for research into the effectiveness of PG and the influence of PG on leadership in an educational setting. To date, little empirical research exists concerning its actual effectiveness or its influence on the organization (Williams, 2010). The fact that PG has made its way into the education sector and schools of choice seek to establish governing boards to facilitate organizational effectiveness indicate a specific need to understand the influence of PG in education.

Table 1

Theoretical Foundation of Policy Governance: Expectations of Involved Parties 


\begin{tabular}{ll}
\hline Party & \multicolumn{1}{c}{ Expectation } \\
\hline Itself & $\begin{array}{l}\text { The board must enunciate the expectations it has of its own operation, its use of } \\
\text { officers and committees, its knowledge base, its connectedness to the } \\
\text { ownership, its manner of delegating to others, and its method of monitoring its } \\
\text { delegates. } \\
\text { The CEO, by whatever formal title, reports to the board and is the recipient of all } \\
\text { executive authority passed into the operating organization. This officer is held } \\
\text { accountable by the board for organizational performance. The board must } \\
\text { provide direction to its CEO in such a way as to preserve board accountability } \\
\text { while maximizing CEO flexibility, creativity, and freedom. } \\
\text { Its CEO } \\
\text { The board must demand certain performance from its chair, as it will authorize } \\
\text { its chair to make decisions on its behalf. The chair's authority to make decisions } \\
\text { will be in an area separate from that given to the CEO. } \\
\text { From time to time, a board may find it helpful to have certain tasks carried out } \\
\text { by smaller groups, particularly the task of gathering information and seeking } \\
\text { options. It is important that such committees or task forces work in the service } \\
\text { of the board and spend only those resources that the board thinks the } \\
\text { committees' products are worth. }\end{array}$ \\
Its Committees
\end{tabular}

\section{Methods}

The purpose of this longitudinal qualitative case study was to gain an understanding of leader perceptions, both school board and administration, of the implementation of a newly adopted governance model, Policy Governance (Carver, 1997, 2001), on leadership capacity in a private, independent school in the Midwest. This board facilitated a change from a traditional stewardship model of board governance to PG in the Fall of 2012 when severe dissatisfaction with the, then current, governance structure peaked. This dissatisfaction was primarily caused by long, arduous board meetings, role conflict leading to tensions between the governing board and administrators, and inefficiency in decision making processes due to multiple sources of input for daily, inconsequential decisions (Participant Interview, 2012).

Data were gathered from Fall 2012 through Summer 2017. A longitudinal approach provided an opportunity to understand the initial influence of PG and factors that either enhanced or threated its sustainability. Further, this school provided an opportunity to understand the influence of a change in governance in a school that had operated under a traditional stewardship model of governance for over 30 years. Understanding the influence of a change in governance is important due to the fact that, as schools grow and mature, turbulent times emerge as "the school leader and board members wrestle with increased diversity of thought and changing roles, authorities, and decision-making systems" over time (Charter Board Partners, 2012, p. 4).

Purposeful sampling was utilized to gather data from "information-rich cases for study in depth" (Patton, 2002 , p. 230). The choice of case study methodology is appropriate when a researcher cannot manipulate behavior of participants in the study and when the researcher believes that contextual conditions are relevant to the phenomenon under study (Yin, 2003). This independent district, established in 1989, has, 
historically, operated under the governance of a self-perpetuating governing board. Before the transition to PG, the board consisted of 12 elected members with four members rotating off each year and four new members rotating on. Board members were appointed to three-year terms with the opportunity to renew their board positions for one additional three-year term (for a total of six years). One member served as Secretary, one served as the Vice-Chairman, and another served as the Chairman. It was assumed that the Vice-Chairman would take the position of Chairman the following year. Advisory members consisted of each chairperson of 12 board committees. These committees had evolved over time, and board committees functioned to provide stakeholder influence into almost every aspect of the organization. Examples of board committees included an Education Committee, Finance Committee, Athletic Committee, Student Affairs Committee, Development Committee, Spiritual Life Committee, and Fine Arts Committee. Board committees met during the first two weeks of each month, and school administrators were required to attend each of these meetings. Membership on board committees consisted of one administrator, one board member, and five to seven parents of students in the school. Board records also indicated that each committee reported to the board at monthly board meetings, resulting in board meetings that lasted between two and three hours.

This district enrolls just over 1,000 students in grades PreK-12. Approximately 100 students graduate from high school each year, and the district maintains several accreditations including AdvanceEd and State accreditation. The district consists of three school levels, each with its own principal over elementary, middle and high school, operating in the same building under the leadership of a Superintendent/Headmaster. AdvanceEd recognizes the school as a "district" even though all schools (elementary, middle and high school) operate primarily in the same building. The building where the school is located was built as a public school building in the early 1980s. Redistribution of boundaries within the public school district left the building unoccupied and available for purchase. In 1992, existing board members purchased the building, and the school has remained in that location since that time. The district employs one Superintendent (referred to as "Headmaster" from this point forward), one High School Principal, one Middle School Principal, one Elementary School Principal, a School Counselor and School Nurse. Approximately 70 certified teachers are employed representing an approximate 15:1 student to teacher ratio. The new Headmaster had been employed by the district for seven years (as the Chief Financial Officer/Assistant Superintendent from 2005-2010 and then Superintendent from 2012present); the High School Principal had been in his position for four years; the Middle School Principal had been in his position for 15 years; and the Elementary Principal had been in his position for 21 years. The Headmaster left the school and the state in $\mathbf{2 0 1 0}$ for two years and returned as Headmaster in 2012.

Perceptions of toxic relationships between board members and the former Headmaster and perceptions of entanglement of board members in day-to-day management responsibilities of the school caused the Chairman of the Board, in 2011, to evaluate alternative governance models (Participant Interview, 2014). As a result, Policy Governance was chosen and implemented in the fall of 2012. Additionally, the previous Headmaster submitted his resignation in the spring of 2011, creating an opportunity to implement a new governing model with the integration of new district leadership. Although change in leadership coinciding with implementation of the new governance model could be interpreted as a limitation of the study, the fact that the incoming Headmaster was a former CFO who served as Assistant Headmaster helps to minimize the effect of this factor on findings in the study. The age of the district, a rich heritage of highly involved parents and community members, and the fact that this district is governed by an independent board provided a unique opportunity to dig deeply into the process of systemic change at all levels of the organization. 


\section{Data Sources}

Data derived from interviews, field notes, observations and documents were collected and then thematically coded (Strauss \& Corbin, 1998). Ten interviews lasting one hour to ninety minutes were conducted in the Fall of 2013 and Spring of 2014 after the first year of implementation of PG. The past Chairman of the Board, current Chairman, Vice-Chairman, Superintendent, three principals and three faculty members were interviewed. All interviews were recorded and transcribed into computer files. Transcripts were sent to participants for member checking. Yin (2003) suggests the use of propositions when analyzing data to place limits on the scope of the study. The propositions that were utilized in this study were based on the theoretical foundation of PG: the expectations of involved parties (Table 1). The theoretical foundation outlines expectations for the following groups: the board itself, the CEO (Headmaster), the Board Chair and board committees. Open code procedures were used to create information categories from data based on meaning that emerged. Examples of participant's words were recorded, and properties of each code were identified and thematically coded (Riessman, 2008). After the completion of open coding, axial coding techniques were used to identify relationships among codes and to develop coherent categories of major and minor themes that emerged (Strauss \& Corbin, 1998). Resulting themes included empowerment, accountability, focus on vision and mission, collaboration, essential leadership characteristics and threats to sustainability.

Triangulation of data was utilized. Observations of town hall, board and parent meetings, board training sessions, interactions of faculty during the school day, interactions between counselors and parents, and school sponsored community outreach initiatives were carefully documented. Document analysis consisted of careful reading of board minutes, the school's policy manual, correspondence between the school and community, and copies of transcripts from interviews that board members had previously conducted with sixteen other schools across the nation that had adopted PG before 2012. These documents provided substantial feedback about the experiences of other independent schools which had implemented PG and provided a foundation for understanding the challenges that this board faced with implementation and sustainability. Follow up interviews were conducted with each participant after the third year of implementation (Fall 2015) to confirm sustainability and to validate initial findings of the study. Additional interviews were conducted in the Spring and Summer of 2017 for a total of 25: interviews across Fall 2013 and Spring 2014 (10), Fall 2015 (10), and Spring/Summer 2017 (five).

\section{Findings}

Findings from this study suggest that the shift to PG had an immediate positive influence on leadership practices and culture in the district. Participants identified the factors of clearly defined performance goals for the Headmaster and autonomy that resulted from delegation of authority for decision making (one of the tenets of PG) had enhanced a culture of professionalism, creativity and distributed leadership. However, implementation of PG posed many challenges. The primary challenges included a complete "paradigm shift" in roles and responsibilities of administrators and the governing board. Embedded in this paradigm shift is the threat to sustainability due to pressure to deviate from the PG model and rely on former methods of governance. A consistent, almost dogmatic focus, by the Chairman of the Board was perceived as a protective factor for sustainability. Each of these findings is discussed more specifically in the following sections.

\section{Policy Governance and the Roles of Administrators and Board Members}

Finding from this study suggest that PG influenced an immediate change in the roles and responsibilities of administrators and board members. When participants described the history of the school, they stated 
that the school was started by a group of "fiercely dedicated individuals" (Participant Interview, 2013). At the inception of the school, previous board members "reached deeply into their pockets" (Participant Interview, 2013) to provide necessary funding to secure the current school facilities. At that time, board members assumed key leadership positions within the organization, including administrative, admissions, and financial management positions. As the school grew, a Headmaster was hired and, eventually, principals (elementary, middle and high school) were hired to perform administrative functions. A Chief Financial Officer was hired in 2005 and a Director of Development was hired in 2006 to facilitate fundraising efforts. However, the function of the school board had not changed even though administrative positions had been added.

All participants indicated that the primary factor that led to the transition to PG was conflict created by continued, intense board involvement in day-to-day management responsibilities of the school influenced by the committee structure from the previous model of governance. For example, the Student Affairs committee, one of twelve board committees involving parents and board members, was responsible for providing input for disciplinary policies of the school. Because several committee members (also board members) were parents of students in the school, these committee members often interpreted the need for change in disciplinary policy through the information that they had received from their children at home. Much of this information was incomplete or incorrect, and administrators were often "on the defensive" (Participant Interview, 2013) concerning disciplinary actions that had been taken. Protection of student privacy required that administrators remain silent on specific details of these incidents and the result was often a feeling of being misunderstood, tension and unresolved conflict.

As the school had grown, board committees had grown in number and size. At the time that the transition was made to PG, twelve board committees included over 100 committee members. Administrators described previous involvement of board members as "exhausting," "inefficient," "hindering" and "a duplication of efforts." One member of the board explained that he would not have continued as a member of the board if the change in governance had not been made. The words he used to describe the former governance model were "exhausting," "completely unproductive," and "meddlesome." Similarly, the administrators described the former governance model as "exhausting," "time consuming" and "extremely inefficient." Teachers described board involvement in management decisions as "heavy," and one stated, "I felt like I had to 'look over my shoulder all of the time to be sure that I didn't offend a board member. I could not make even a simple decision for my department."

In contrast, PG included non-negotiable boundaries, or "limitations," that created parameters within which district leaders, board members and the Headmaster must operate. Even though these boundaries are titled "limitations," all administrators in the organization described these limitations as "empowering" and suggested that the "freedom to make decisions" that had emerged from the new framework was energizing. Specifically, clearly defined roles and responsibilities under PG had allowed them to make independent decisions that, formerly, would have involved consultation with board members. One administrator stated:

I simply could not bear hearing the discussion at one more board meeting of what color of uniform shirts would be permitted for students. It was such a waste of time. It seems like we had that conversation every year, even several times a year. Now, we simply make a decision and move forward.

Teachers also mentioned the opportunity to make decisions about curriculum, such as summer reading, in a more efficient manner. A teacher explained, "I don't have to be certain that I have the approval of the board when I make decisions." Another explained, "we are professionals. We know how the choices we 
make fit into the overall curriculum of our courses. We shouldn't have to consult parents or board members about making even the most minor choices. It's exhausting."

Former board committees were dissolved when PG was implemented. Instead, board members were responsible for "looking forward to secure the future of the school" (Participant Interview, 2013). As a result, administrators began to work more collaboratively with each other to address issues that were previously handled at the committee level. For example, instead of discussing curriculum issues during Education Committee meetings, teachers worked collaboratively with each other during department meetings to make curriculum decisions. A teacher described the process as "refreshing and productive." Teachers described the feeling that they had as "more trusting," "freeing," "liberating" and, as one teacher explained, "I feel like I can breathe." Of note, a teacher in the high school explained that, if the former model had continued, she had planned to leave the school due to the "exhausting and draining" environment of always having to "check with board members" before making decisions for her program.

Board members also articulated a change in perception of their roles within the organization. "Putting organizational goals ahead of personal goals" was emphasized as a requirement for board membership. Board members stressed that they "could not be 'single-issue' focused," but instead, PG required a primary focus on the long-term success of the school. A board member explained, "our membership on the board does not mean we get our way in issues that personally concern us. Instead, we have to trust the administration to manage the school." Similarly, another board member stressed the fact that she had initially joined the board because she was concerned about specific discipline issues at the school. She stated, "I learned that I have to leave those decisions to administrators. That's not my job anymore." The Chairman and Vice-Chairman of the board emphasized the board's responsibility to "maintain a forward focus" to secure the future of the organization rather than "becoming entangled in day- to-day management decisions of the school."

Relationships between the Headmaster and members of the board changed also. The Headmaster described his relationship with the board as one of "intense accountability with deep levels of trust to make decisions." He described his responsibility to report to the board each month concerning "ends" goals as "stringent," and he explained that this responsibility caused him to continuously reflect on the performance of the organization. Likewise, each administrator expressed enhanced freedom in decisionmaking, and explained that their roles seemed "less complicated" than under the former model. One administrator explained, "I was hired as a professional, and now I am treated as a professional. Now my decisions and judgments seem like they matter."

The Headmaster expressed confidence in his ability to lead his staff. He indicated, "my staff report directly to me. I do not worry that they are receiving conflicting information from me and from board members." Further, the Headmaster emphasized that he intended to move the organization toward a "more collaborative culture within the organization." He described his philosophy of including others, both administrators and teachers, in decision-making. This leader emphasized confidence in his administrators and stated, "I trust them as professionals to make the decisions that are in the best interest of students. If I can't trust them to do make good decisions, they should not be working here."

Interestingly, an unexpected finding was that the Headmaster's collaborative leadership style seemed to "trickle down" through the organization. Building level administrators also indicated that they had become increasingly willing to delegate decision-making to teachers. One administrator explained, "teachers here are competent and capable. I trust them to make (curricular) decisions." This "trickle down" effect of distributing and delegating decisions seemed to enhance a trusting culture in the organization as the word "trust" was the most frequently coded word in the study. The resulting effect 
was the perception, across administrators and teachers, of a more trusting culture and the promotion of shared leadership responsibilities throughout all levels of the organization.

\section{Sustainability: The Challenge of Policy Governance}

The findings suggest that the choice to implement PG was a well-informed decision. Diligent efforts of the board to investigate the effectiveness of PG before the model was implemented were apparent. Before deciding to move to PG, board members identified 16 independent schools across the United States that had adopted the model. Individual board members conducted extensive research into the effectiveness of PG in those environments including telephone conversations with board members and administrators, a school site visit, and careful inspection of student outcomes or other evidence of educational success at each school such as graduation rates or college acceptance rates. Additionally, once the data from each school was collected, they gathered together to discuss their findings and to discuss implications for adoption of PG. Each board member read Carver's (1990) book Boards that Make a Difference, and each member was required to vote "for" or "against" the proposed model. The board voted unanimously to adopt PG and, then, as described by the Chairman of the Board, the "hard work began."

All board members and administrators described the implementation of PG as extremely tedious and time consuming. Specific emphasis was attributed to the importance of the leadership of the Past-Chairman of the Board for implementation. Further, as the literature on PG explains (Carver, 1990), extensive time was needed to establish "limitations" and "ends" (outcome goals of the organization by which the Headmaster's performance would be measured). The board met four times for Saturday planning meetings during the spring of 2012 and three extended weekend board retreats during the summer of 2012 (for a total of seven extended board planning/training meetings) to establish "ends" and "limitations" policies.

Further, administrators and board members explained that the PG model included a "complete paradigm shift" that required a strong commitment and strict adherence to the model. A board member explained that "it became quickly apparent that we couldn't go into this process with partial commitment. It had to be an 'all or nothing' endeavor." The Chairman was firmly convinced that securing commitment from all existing board members was essential, and the Chairman and Vice-Chairman explained that sustainability of the model required a commitment of time during each monthly board meeting for continued training. Follow-up interviews during the fall of 2015 indicated that 10-15 minutes of board training had continued at each monthly meeting since the adoption of PG. Follow-up interviews in the Spring of 2017 indicated that board training had continued.

\section{Challenges to Sustained Effectiveness and Safeguards for Sustainability}

A common theme that emerged from all stakeholder groups was a persistent threat of "board take over" in the event of a crisis. The types of potential crises mentioned were any contextual/community event that could reduce student enrollment (such as changes in the economy), threats to the safety of students on campus, or behavior of an administrator or teacher that required immediate action or had legal ramifications. One board member questioned, "if a crisis arises, will it be 'business as usual?' or will we be inclined take over and make management decisions for the organization again?" Conflicting perceptions between board members were noted as two board members were concerned about "reverting back" to former board practices while another board member suggested that a "return to board management may be needed" in the event of a crisis. Another important aspect for sustainability of PG was the importance of recruiting board members, and especially a Chairman, who could commit to strict 
adherence to PG. A board member stated, "A 'single issue' board member could derail this process pretty quickly."

Strong leadership characteristics for the Headmaster and Chairman were emphasized as essential elements for sustainability. Characteristics of the Headmaster included trustworthiness, professionalism, competence, humility, trust, integrity, communication skills, decision-making ability, transparency, listening skills, and the ability to delegate tasks and responsibilities. The importance of trust was explained in the statement "if we don't have a Headmaster that we can trust to make important decisions, this model will not work at all. Delegation of management authority is essential." Necessary leadership characteristics for the Chairman included courage, confidence, commitment to PG, devotion to the organization, selflessness and trustworthiness. These characteristics centered mostly on defending and perpetuating PG to secure the future of the organization rather than promoting specific evidence of organizational success. Instead, organizational success was primarily identified as a responsibility of the Headmaster. Continual, monthly monitoring of Headmaster progress and monthly board training was identified as essential for sustainability. The Headmaster has been held accountable to the board each month during board meetings regarding meeting "ends" goals as outlined by the board. At times, the Headmaster invited key administrators or teachers to discuss progress towards "ends" goals, allowing him to practice distributed leadership by utilizing the expertise of others. However, the Headmaster maintained ultimate responsibility for program outcomes.

Evidence from follow-up interviews suggests that, although PG has been sustained through its fifth year of implementation, challenges to sustainability continue. The leadership of the board has changed once since the inception of PG, and the Chairman in place during implementation has remained available for advice/support. Because this (now former) Chairman initiated the change through a strong, almost "laser like," focus on adherence to PG, board members insisted that his influence remains important for sustainability. Challenges were noted from data collected in Spring and Summer 2017 that apathy among board members to fulfill organizational goals had emerged. One participant explained, "Policy Governance worked well in the beginning, but there seems to be a lack of interest at board meetings now." Another explained, "I (a board member) don't feel like I have a purpose other than staying true to Policy Governance. Am I really making a difference here? I wonder about that. I don't know how important my work really is." Key administrators at the school also expressed concern about sustainability of PG. One stated:

I get it. I understand that criticisms of sustainability are often perceived as lack of adherence to the model. There's not another school that has tried as hard as we have. But there's no energy now. I feel like no one is really invested anymore.

\section{Discussion}

This school's history of governance aligns with the "historical model" of nonprofit agency governance outlined by Marx and Davis (2012). They suggest that social organizations typically begin as "voluntary associations of like-minded individuals attempting to meet some need and/or promote some cause" (Marx \& Davis, 2012, p. 41). At inception, volunteers are needed to complete responsibilities, including management of the organization (Marx \& Davis, 2012). As the organization grew and matured, staff members were hired to support the volunteers in their work, and roles and responsibilities within the organization became "murky" (Marx \& Davis, 2012, p. 41). This finding is important because the maturation of an organization is an inevitable, yet often unplanned for, evolution of school management and governance. However, when organizations fail to plan for this maturation process, conflict often results. The blurring of lines of responsibility and authority can cause inefficiency and strong dissention 
within an organization over time (Moe, 2000). Finding a model of governance that can "grow and mature" with the school is an important step in meeting organizational goals. In this study, the implementation of PG in its initial implementation stages provided the delegation of authority needed to support this school at that point in time.

An important finding from this study was that this Headmaster's strong emphasis on collaboration across the district seemed to facilitate a "trickle down" effect of shared decision making. While this finding is important, delegation of authority and strict adherence to roles and responsibilities resulted in apathy approximately five years after implementation. The energy at the board level diminished over time to the point that board members were questioning the importance of their involvement. This finding is consistent with the other findings on sustainability of PG. However, these findings have been criticized as "lack of adherence to the model" (Carver, 2010; Williams, 2010). What findings from this study offer is a similar result even though this board was diligent to follow the model with fidelity. This finding is important because it was expected that PG would energize the board to fulfill board responsibilities of vision casting and securing the future of the organization (Carver, 2010). However, the apathy that has resulted indicates that changes or alternations will be needed in the future. Additional research is needed to understand how this board responds to emerging needs under PG. What emerges from these findings, however, is that simply regarding the challenges as "failure to adhere strictly to the model" (Carver, 2010) is not an adequate explanation.

What was especially interesting was this organization's ability to make such a significant change in governance after being in existence for almost 30 years. Findings in the literature explain that systems change can be exceptionally difficult (Fullan, 2004) and that it is enormously difficult for schools to reinvent themselves (Bennett, 1992; Woods-Murphy, 2016). What was evidenced in this study was the ability to make the change in a relatively short period of time (less than one year). This change came at a time when board/administrator tensions were high, and the opportunity to hire a new leader was present. Identifying key "change opportunities" may be important for making the kinds of changes needed that may influence the entire system. What seemed most evident was the pairing of opportunity for change with strong board and Headmaster leadership. In this study, commitment from the Chairman to change the governance of the school preceded the hiring of the new Headmaster. The board was able to make key changes in governance philosophy and hire a Headmaster to support those changes.

Also, interesting to note is that this shift in governance required each board member to relinquish control of involvement in management responsibilities of the school. Because of such strong board support of PG, board members who had come onto the board as "single issue board members" had to make the decision of whether to remain on the board and relinquish control or to resign from the board. The finding that unanimous, individual board member commitment to PG was required for implementation underscores the importance of selecting new board members who can commit to the model. It also underscores the inevitability of the entrance of threat of lower commitment with the passage of time. For example, as new members are brought onto the board, and these new members forget or are unfamiliar with "toxic" ways of the past, the board may have the tendency to revert to a management stance, especially if board members enter the board with a "single issue" focus. While PG served as a "refreshing" structure to help clarify roles and responsibilities of the board and Headmaster, challenges to sustainability are evident. Further research is needed to understand how PG can be sustained as board or superintendent leadership changes through time.

\section{Limitations}


This school had the opportunity to select a Headmaster whom they perceived could be successful under PG at its implementation phase. Further research is needed on the sustainability of PG in schools that have existing leadership or schools with leaders who possess different characteristics. Findings in this study may reflect this Headmaster's leadership capacity as much as the influence of PG on the organization. However, it is also likely that this Headmaster's leadership capacity was enhanced by PG in that he was granted autonomous authority for managing the organization.

\section{References}

Allen, A. \& Mintrom, M. (2010). Responsibility and school governance. Educational Policy, 24(3), 439-464.

Basinger, N. M. \& Grabner-Hagen, M. M. (2014). Charter school governance: A state- level analysis of policies. Journal for Non-Profit Management, 17(1), 4-19.

Berliner, D.C. \& Biddle, B.J. (1996). The manufactured crisis: Myths, fraud, and the attack on America's public schools. NASSP Bulletin, 80(576),119 - 121. Retrieved from https://static1.squarespace.com/static/55e72334e4b004a111a82a59/t/56a163401a5203f60 ef8c6e8/1453417291700/The+Manufactured+Crisis.pdf

Bennett, D. A. (1992). Will public/private control reinvent school system governance? Education Digest, 92(58), 30-33.

Carver, J. (1997). Boards that make a difference ( $2^{\text {nd }}$ ed.). San Francisco, CA: Jossey-Bass.

Carver, J. \& Carver, M. (2001). Carver's PG Model in nonprofit organizations. Revue Internationale, 2(1), 30-48.

Carver, J. (2010). A case for a global governance theory: Practitioners avoid it, academics narrow it, the world needs it. Corporate Governance: An International Review 18(2), 149-157.

Charter Board Partners (2012). Governance best practices for highly effective charter school boards. Retrieved from www.publicharters.org/wp-content/uploads/2014/09/Paper-Governance-BestPractices-for-Hightly-Effective-Charter-School-Boards.pdf

Charter Friends National Network (2000a). Charter schools: Creating effective governing boards. Charter Friends National Network. Retrieved from www.charterschoolcenter.org/sites/default/files/field_publication_attachment/Creatingeffective-governing-boards.0pdf

Charter Friends National Network (2000b). Creating an effective charter school governing board. National Charter School Resource Center. Retrieved from www.charterschoolcenter.org/resource/creating-effective-charter-school-governing-boardfull-version

Every Student Succeeds Act of 2015, S. $1177\left(114^{\text {th }}\right)$. U.S. Department of Education. Retrieved from https://www.ed.gov/esea

Ford, M. R., \& Ihrke, D. M. (2017). Board conflict and public performance on urban and non-urban boards: Evidence from a national sample of school board members. Journal of Urban Affairs, 39(1), 108-121.

Fullan, M. (2004). Leadership and sustainability: System thinkers in action. Newbury Park, CA: Corwin Press. 
Gawlik, M. A. (2015). Shared sense-making: How charter school leaders ascribe meaning to accountability. Journal of Educational Administration, 53(3), 393-415.

Hopkins, M. M., O'Neil, D. A., \& Williams, H. W. (2007). Emotional intelligence and board governance: Leadership lessons from the public sector. Journal of Managerial Psychology, 22(7), 683-700.

James, C., Jones, J., Connolly, M., Brammer, S., Fertig, M., \& James, J. (2012). The role of the chair of the school governing body in England. School Leadership \& Management, 32(1), 3-19.

James, C., Brammer, S., Connolly, M., Fertig, M. James, J., \& Jones, J. (2010). The 'hidden givers'” A study of school governing bodies in England. Berkshire: CfBT Education Trust.

Jennings, J. (2015). ESEA at 50. Phi Delta Kappan, 96(7), 41-46.

Kapalka Richerme, L. (2012). Remain or react: The music education profession's responses to "Sputnik" and "A Nation at Risk." Arts Education Policy Review, 113(1), 35-44.

Karanxha, Z. (2013). When the "dream" turns into a nightmare: Life and death of Voyager Charter School. Educational Administration Quarterly, 49(4), 576-609.

Kirst, M. W. (2002). Mayoral influences, new regimes, and public school governance. CPRE Research Reports. Retrieved from http://repository.upenn.edu/cpre_researchreports/25

Kirst, M. W. (2007). Politics of charter schools: Competing national advocacy coalitions meet local politics. Politics, Policy, and Organization of School Choice, 82(2-3), 184-203.

Lubienski, C. A. \& Weitzel, P. C. (2010). The charter school experiment: Expectations, evidence, and implications. Cambridge, MA: Harvard Education Press.

Malen, B. (2011). An enduring issue: The relationship between political democracy and educational effectiveness. In D. Mitchell, R. Crowson, \& D. Shipps (Eds.), Shaping education policy: Power and process (pp. 23-60). New York, NY: Routledge.

Marx, J. \& Davis, C. (2012). Nonprofit governance: improving performance in troubled economic times. Administration in Social Work, 36, 40-52.

McGuinn, P. (2015). Schooling the state: ESEA and the evolution of the U.S. Department of Education. RSF: The Russell Sage Foundation Journal of the Social Sciences, 1(3), 77- 94.

Moe, T. M. (2000). The two democratic purposes of public education. In L. M. McDonnell, P. M. Timpane, \& R. Benjamin (Eds.), Rediscovering the democratic purposes of education (Chap. 6). Lawrence: University Press of Kansas.

Murray, V. (2010). Bookshelf review: Reinventing your board. The Philanthropist, 14(4), 57-64.

National Commission on Excellence in Education. (1983). A nation at risk: The imperative for educational reform. The Elementary School Journal, 84(2), 113-130.

National Conference of State Legislatures (NCSL) (2017). School choice and charters. Retrieved from http://www.ncsl.org/research/education/school-choice-and- charters.aspx

National School Boards Association (2015). Leadership for state school boards associations guidebook. Retrieved from https://www.nsba.org/leadership-state- school-boards-associations 
Nobbie, P. D. \& Brudney, J. L. (2003) Testing the implementation, board performance and organizational effectiveness of the PG Model in nonprofit boards of directors. Nonprofit and Voluntary Sector Quarterly, 32, 571-595.

Oliver, C. (1999). The PG Fieldbook: Practical lessons, tips, and tools from experiences in real-world boards. San Francisco, CA: Jossey-Bass.

Patton, M. Q. (2002). Qualitative research and evaluation methods. Thousand Oaks, CA: Sage.

Posamentier, J., Lake, R., \& Hill, P. (2017). How states can promote local innovation, options, and problem-solving in public education. Retrieved from https://www.crpe.org/publications/statespromote-local-innovation

Poultney, V. (2013). Personal reflections on the governing of private schools: A case study. Management in Education, 27(3), 91-95.

Public Agenda (2001). Trying to stay ahead of the game. Public Agenda, New York, NY.

Race to the Top Act of 2011, H.R. $152\left(112^{\text {th }}\right)$. U.S. Department of Education. Retrieved from www2.ed.gov/programs/racetothetop/index.html.

Riessman, C. K. (2008). Narrative methods for the human sciences. California: Sage.

Resnick, M. A. (2006). An American imperative: Public education. Center for Public Education. Retrieved from http://www.centerforpubliceducation.org/Main-Menu/Public-education/An-Americanimperative-Public-education-

Sampson, C. R. (2017). So It "became white activists fighting for integration?" Community organizations, intersectional identities, and education reform. Urban Review: Issues and Ideas In Public Education, 49(1), 72-95.

Scott, J. C. (1998). Seeing like a state: How certain schemes to improve the human condition have failed. New Haven, CN: Yale University Press.

Smith, J. J. (2003). Administrative evaluations and their impact on school leadership in public and private secondary schools: A comparison study of governance structure (Doctoral dissertation). Retrieved from ProQuest (2003.3133337)

Strauss, A. \& Corbin, J. (1998). Basics of qualitative research. Thousand Oaks, CA: Sage.

Useem, E. (2009). Big city superintendent as powerful CEO: Paul Vallas in Philadelphia. Peabody Journal of Education, 84(3), 300-317.

Weiler, H. N. (1983). Education, public confidence and the legitimacy of the modern state: Is there a crisis' somewhere? Journal of Curriculum Studies, 15(2), 125-142.

Wilcox, J. (2014). Directors should communicate with shareholders. Harvard Law School Forum on Corporate Governance and Financial Regulation. Retrieved from https://corpgov.law.harvard.edu/2014/10/16/directors-should-communicate-withshareholders/

Williams, A. C. (2010). New and improved?: A case study of nonprofit Policy Governance. Human Organization, 69(3), 295-395. 
Woods-Murphy, M. (2016). Perceptions of highly recognized teachers about approaches to teacher leadership (Unpublished doctoral dissertation). Walden University.

Yin, R. K. (2003). Case study research: Design and methods ( $3^{\text {rd }}$ ed.). Thousand Oaks, CA: Sage.

\section{About the Authors}

Katherine Curry (katherine.curry@okstate.edu) is the John A. and Donnie Brock Professor of Educational Leadership and Policy Studies at Oklahoma State University in Stillwater, Oklahoma. She is also Program Chair for the Educational Leadership/School Administration program in the School of Educational Foundations, Leadership and Aviation. Her research interests include family engagement in education, social network analysis, school governance, school choice, and school reform.

Sean Kinder (sean.kinder@okstate.edu) is a doctoral candidate in the Educational Leadership and Policy Studies/Educational Administration program at Oklahoma State University in Stillwater, Oklahoma. His research interests include educational leadership and leadership for individuals with disabilities.

Tania Benoiton (tania.benoiton@okstate.edu) is doctoral candidate in the Educational Leadership and Policy Studies/Educational Administration program at Oklahoma State University in Stillwater, Oklahoma. Her research interests include teacher mentorship and social network analysis. She hopes to continue her research agenda at education non-profits and developing projects and programs in collaboration with private and government institutions focusing on teacher and student leadership.

Jessica Noonan (jessica.noonan@okstate.edu) is a Ph.D. student in the Educational Leadership and Policy Studies/Educational Administration program at Oklahoma State University in Stillwater, Oklahoma. Her research interests include family and community engagement, educational equity, and teacher preparation. 